\title{
Estrogen receptor- $\beta$ is expressed in stromal cells of fibroadenoma and phyllodes tumors of the breast
}

\author{
Anna Sapino ${ }^{1}$, Martino Bosco ${ }^{1}$, Paola Cassoni ${ }^{1}$, Isabella Castellano ${ }^{1}$, Riccardo Arisio ${ }^{2}$, \\ Gábor Cserni ${ }^{3}$, Angelo P Dei Tos ${ }^{4}$, Nicoletta Fortunati ${ }^{5}$, Maria G Catalano ${ }^{6}$ \\ and Gianni Bussolati ${ }^{1}$ \\ ${ }^{1}$ Department of Biomedical Science and Human Oncology, University of Torino, Torino, Italy; ${ }^{2}$ Department of \\ Pathology, Sant'Anna Hospital, Torino, Italy; ${ }^{3}$ Department of Pathology, Bacs-Kiskun County Teaching \\ Hospital, Kecskemet, Hungary; ${ }^{4}$ Department of Pathology, Regional Hospital, Treviso, Italy; ${ }^{5}$ Oncological \\ Endocrinology, ASO San Giovanni Battista, Torino, Italy and ${ }^{6}$ Department of Clinical Physiopathology, \\ University of Torino, Torino, Italy
}

\begin{abstract}
An estrogen dependency has been suggested for the growth of fibroadenomas: however, thus far, none of the steroid hormone receptors acting on breast tissues has been demonstrated in the stroma of breast fibroepithelial lesions. In this study, the expression of estrogen receptor (ER)- $\alpha$ and $-\beta$ was investigated by immunohistochemistry in $\mathbf{3 3}$ fibroadenomas and in $\mathbf{3 0}$ benign, three borderline and seven malignant phyllodes tumors, all with spindle cell growth and in one distant metastasis. In addition, the presence of ER- $\beta$ mRNA and its variants was evaluated by RT-PCR in microdissected stroma. The possible correlation between hormone receptor expression and differentiation processes of stromal cells was investigated by smooth muscle actin and calponin immunostaining. ER- $\beta$ was the only hormone receptor expressed by stroma of fibroadenomas and phyllodes tumors, both at protein and mRNA level. The highest percentage of ER- $\beta$ was observed in fibroadenomas with cellular stroma and in phyllodes tumors. In both lesions, ER- $\beta$-positive stromal cells showed expression of smooth muscle actin and/or calponin, as demonstrated by double immunostaining. In addition, the mean age at diagnosis was significantly lower in patients with ER- $\beta$-positive vs ER- $\beta$-negative fibroadenomas. In contrast, in phyllodes tumors, ER- $\beta$ expression was higher in older patients. In conclusion, (i) only ER- $\beta$ is detected in the stroma of fibroadenomas and phyllodes tumors; (ii) its expression correlates with the expression of smooth muscle markers and suggests a role of ER- $\beta$ in myofibroblastic differentiation of stromal cells. These two results, together with the young age of patients carrying fibroadenomas with highly ER- $\beta$-positive stroma cells, may further indicate a hormone-receptor mechanism involved in regulating the growth of fibroadenomas. Conversely, the older age of patients with ER- $\beta$-rich phyllodes tumors suggests that mechanisms, probably independent from estrogen stimulation, act on the growth of these tumors.
\end{abstract}

Modern Pathology (2006) 19, 599-606. doi:10.1038/modpathol.3800574

Keywords: ER- $\beta$; fibroadenoma; phyllodes tumor

Fibroadenoma and phyllodes tumor are biphasic lesions of the breast characterized by proliferation of both epithelial and stromal components of the terminal ductal unit. Proliferation of stromal cells is commonly considered the primary event, followed by secondary proliferation of epithelial cells. While studies on stromal cell clonality have shown

Correspondence: Dr A Sapino, MD, Dipartimento di Scienze Biomediche e Oncologia Umana, Università di Torino, Via Santena 7, Torino 10126, Italy.

E-mail: anna.sapino@unito.it

Received 13 November 2005; revised and accepted 10 January 2006 that malignant phyllodes tumors are neoplastic, most fibroadenomas are considered a result of hyperplastic processes involving the connective tissue of lobular units. ${ }^{1}$ The natural history of fibroadenomas varies. They may grow, regress or remain unchanged, as the hormonal environment of the patient changes, but most stop growing after reaching $2-3 \mathrm{~cm}$ in diameter; ${ }^{2}$ moreover, with aging, the stroma becomes less cellular and increases its hyalinization. ${ }^{3}$ These data (occurrence in young women and sclerotic involution in the elderly) suggest a hormonal responsiveness of fibroadenoma. This hypothesis is supported by the recent finding of elevated plasma levels of estradiol in patients 
with fibroadenoma. ${ }^{4}$ In the same patients, singlenucleotide polymorphisms of genes encoding for enzymes involved in estrogen metabolism have also been demonstrated. ${ }^{5}$ In addition, tamoxifen treatment significantly reduces the proliferation activity in the stroma of fibroadenomas. ${ }^{6}$ The classical mediator of the response to estradiol and tamoxifen is the estrogen receptor (ER)- $\alpha$, but in fibroadenomas and phyllodes tumors, ER- $\alpha$ is mainly expressed by epithelial cells, while its expression by stromal cells is controversial. ${ }^{7-10}$ A recent study demonstrated that only the ER- $\beta$ isoforms are found in stromal cells of the adult human mammary gland. ${ }^{11}$ All these data taken together motivated us to investigate whether ER- $\beta$ could be expressed by the stromal cells in fibroadenomas and phyllodes tumors. In addition, following the recent observation of both the common smooth muscle cell differentiation in fibroepithelial lesions of the breast ${ }^{12}$ and the high levels of ER- $\beta$ in muscle cells of other estrogendependent organs, ${ }^{13}$ we decided to investigate the immunophenotype of the stromal cells using smooth muscle actin and calponin as markers.

\section{Materials and methods}

\section{Case Series}

We selected a series of 35 fibroadenomas and 30 benign, three borderline and seven malignant phyllodes tumors with fibrosarcomatous differentiation diagnosed in the four Pathology Departments. One of the cases gave rise to lung metastasis. All cases of fibroadenomas were reviewed and classified on the basis of stromal sclerosis and grade of cellularity. Sclerotic fibroadenomas were generally no more than $1 \mathrm{~cm}$ in diameter, and showed low cellularity with scattered thin spindle cells intermingled with bundles of sclerotic stroma. Cellular fibroadenomas were often larger than the sclerotic type (mean diameter $1.5 \mathrm{~cm}$ ), their stroma was more myxoid and oedematous and was richly populated by cells with long extensions protruding from the large polygonal cytoplasm.

\section{Immunohistochemistry}

All specimens were fixed in $4 \%$ formalin and embedded in paraffin. For immunohistochemistry, the endogenous peroxidase was inhibited by incubating specimens with $3 \% \mathrm{H}_{2} \mathrm{O}_{2}$ for $5 \mathrm{~min}$ prior to incubation with the primary monoclonal antibody. To study the hormone receptor status, sections were incubated with anti-ER- $\beta$ (clone 14C8, Abcam, Cambridge, UK) at a concentration of $5 \mu \mathrm{g} / \mathrm{ml}$ overnight at $4^{\circ} \mathrm{C}$ in an humidified chamber, according to previously validated procedures. ${ }^{14}$ The antibody reaction was revealed by EnVision + System (DakoCytomation, Glostrup, Denmark). Immunostaining was performed with the following antibodies: anti-
ER- $\alpha$ (clone 1D5, diluted 1:100, DakoCytomation), smooth muscle actin (clone 1A4, diluted 1:200; DakoCytomation) and calponin (clone CALP, diluted 1:100; BioGenex, San Ramon, CA, USA) mAbs using the automated immunostainer BenchMark XT (Ventana). Antigen retrieval was performed for all immunohistochemical reactions, with the exclusion of smooth muscle actin, by incubation in termostated bath in $1 \mathrm{mM}$ citrate buffer, $\mathrm{pH} 6$, for $40 \mathrm{~min}$ at $98^{\circ} \mathrm{C}$. Primary antibodies were revealed by the universal iView-Dab detection kit (Ventana Medical System, Tucson, USA).

In two cases (one cellular fibroadenoma and one phyllodes tumor), two-step double immunostaining was performed to evaluate the coexpression of ER- $\beta$ with smooth muscle differentiation markers. In step one, anti-ER- $\beta$ nuclear binding was revealed with a 3,3'-diaminobenzidine solution (brown precipitate). The sections were then washed in phosphatebuffered saline (PBS), incubated for $30 \mathrm{~min}$ at $37^{\circ} \mathrm{C}$ in $0.01 \mathrm{M} \mathrm{HCl}$ and washed thoroughly with water $(\sim 2 \mathrm{~h})$ to remove unbound antibody that could potentially interfere with the second part of the immunohistochemical reaction. In the second step, cytoplasmic binding of anti-smooth muscle actin $\mathrm{mAb}$ was visualized with a solution of $3,3^{\prime}$-diaminobenzidine and $0.3 \% \mathrm{NiCl}_{2}$ in $50 \mathrm{ml}$ of PBS, pH 7.4 (black precipitate).

\section{Microdissection}

To evaluate ER- $\beta$ mRNA expression, tissue samples of three cellular fibroadenomas, one malignant phyllodes tumor and one phyllodes tumor metastasis were frozen in liquid nitrogen and stored at $-80^{\circ} \mathrm{C}$ until use. Two of these fibroadenomas and the phyllodes tumor with its metastasis were microdissected, in order to avoid epithelial contamination and to focus on mRNA of stromal tissue. ER- $\beta$ protein expression in stromal cells was first evaluated by immunohistochemistry. Sections were microdissected with a LaserScissors microdissector (Olympus/Cell Robotics Inc., Albuquerque, NM, USA). The microdissected stromal tissue was collected in microcentrifuge tubes and total RNA was extracted using Trireagent solution (Genomed, Celbio, Pero, Italy) according to the manufacturer's instructions. RNA concentration was measured spectrophotometrically by determination at 260/ $280 \mathrm{~nm}$, its purity and integrity was checked by electrophoresis on a $1.5 \%$ agarose gel.

\section{RNA Extraction and RT-PCR Analysis}

Total RNA obtained from one not microdissected cellular fibroadenoma and from microdissected stromal tissues of the other specimens was extracted using RNeasy Mini Kit (Qiagen GmbH, Hilden, Germany) following the manufacturers' instructions. Positive controls were MDA-MB231 breast cancer 
Table 1 Sequences of ER- $\beta$ and ER- $\alpha$ RT-PCR primers

\begin{tabular}{llc}
\hline Primer & Sequence & Amplification product (bp) \\
\hline ER- $\beta 1-5$ forward & $5^{\prime}$-AGT ATG TAC CCT CTG GTC ACA GCG-3' & 408 \\
ER- $\beta 1$ reverse & $5^{\prime}$-CCA AAT GAG GGA CCA CAC AGC AG-3' & 291 \\
ER- $\beta 2$ reverse & $5^{\prime}$-GGA TTA CAA TGA TCC CAG AGG GAA ATT G-3' & 400 \\
ER- $\beta 3$ reverse & $5^{\prime}$-GCA GTC AAG GTG TCG ACA AAG GCT GC-3' & 608 \\
ER $\beta 4$ reverse & $5^{\prime}$-GGA TTA CAA TGA TCC CAG AGG GAA ATT G-3' & 372 \\
ER $\beta 5$ reverse & $5^{\prime}$-CTT TAG GCC ACC GAG TTG ATT AGA G-3' & \\
ER- $\alpha$ forward & $5^{\prime}$-CAT AAC GAC TAT ATG TGT CC AGC C-3' & \\
ER- $\alpha$ reverse & $5^{\prime}$-AAC CGA GAT GTA GCC AGC AGC-3' & \\
$\beta 2-$ Actin forward & $5^{\prime}$-CTC ACC CTG AAG TAC CCC ATC G-3' & 659 \\
$\beta 2-$-Actin reverse & $5^{\prime}$-CTT GCT GAT CCA CAT CTG CTG G-3' \\
\hline
\end{tabular}

cell line for ER- $\beta$ and MCF-7 breast cancer cell line for ER- $\alpha$. Total RNA was reverse-transcribed at $42^{\circ} \mathrm{C}$ for 40 min using AMV reverse transcriptase (Finnzymes, Finland) and oligodT primer (Invitrogen, Groningen, The Netherlands). The PCR reaction system contained $5 \mu \mathrm{l}$ of $10 \times$ PCR buffer, $10 \mu \mathrm{l}$ of RT product, $0.2 \mathrm{mM}$ dNTP (Finnzymes, Espoo, Finland), 1.25 U Taq DNA polymerase (Finnzymes, Finland), $50 \mathrm{ng}$ each of sense and antisense primers in a total volume of $50 \mu$ l. ER- $\alpha$ and ER- $\beta$ primers are reported in Table 1.

Amplification was carried out as follows: for $\mathrm{ER} \beta$ isoforms, $1 \times\left(94^{\circ} \mathrm{C}, 1 \mathrm{~min}\right) ; 35 \times\left(94^{\circ} \mathrm{C}, 30 \mathrm{~s} ; 58^{\circ} \mathrm{C}\right.$, $\left.30 \mathrm{~s} ; 72^{\circ} \mathrm{C}, 30 \mathrm{~s}\right)$; and $1 \times\left(72^{\circ} \mathrm{C}, 7 \mathrm{~min}\right)$; for ER- $\alpha$ and $\beta$-actin, $1 \times\left(94^{\circ} \mathrm{C}, 1 \mathrm{~min}\right) ; 35 \times\left(94^{\circ} \mathrm{C}, 30 \mathrm{~s} ; 65^{\circ} \mathrm{C}, 30 \mathrm{~s}\right.$; $\left.72^{\circ} \mathrm{C}, 30 \mathrm{~s}\right)$; and $1 \times\left(72^{\circ} \mathrm{C}, 7 \mathrm{~min}\right)$; PCR products were electrophoresed on $2 \%$ agarose gel in the presence of ethidium bromide. Gels were photographed and analyzed with the PC Kodak 1D Image Analysis software (Eastman Kodak Company, Rochester, NY, USA).

\section{Statistical Analysis}

Correlation between ER- $\beta$ expression and stromal cell percentage or smooth muscle differentiation was calculated with $\chi^{2}$ test; correlation between age of patients and ER- $\beta$ expression was calculated with independent samples $t$-test. Statistical analysis was performed with SPSS for windows (V.9.0) software.

\section{Results}

After revision, seven fibroadenomas were classified as low cellular 'sclerotic' and 26 as 'cellular' fibroadenomas.

\section{Immunohistochemistry}

Expression of hormone receptors

ER- $\alpha$ were expressed in epithelial cells, but were not detectable in the stroma of fibroadenomas and phyllodes tumors, while ER- $\beta$ was expressed in both epithelial and myoepithelial cells and in a variable amount of nuclei of stromal cells and endothelial cells of small vessels. Three categories of ER- $\beta$ expression were considered on the basis of the percentage of nuclear staining of stromal cells: 0-5\% (low), 6-30\% (moderate) and 31-100\% (high). In all seven sclerotic fibroadenomas ER- $\beta$ expression was absent or very low (Figures 1a and 2), whereas high and moderate levels of ER- $\beta$ were detected in $16(62 \%)$ and six $(23 \%)$ out of the 26 cellular fibroadenomas, respectively (Figures $1 \mathrm{~b}$ and 2 ). In benign phyllodes tumors, the expression level of ER$\beta$ was high in 14 cases ( $47 \%$ ), moderate in 10 cases $(33 \%)$ (Figure 1c) and low in six cases (20\%). All borderline phyllodes tumors (Figure 1d) and 4/7 $(57 \%)$ of the malignant phyllodes tumors together with the lung metastasis displayed high ER- $\beta$ expression (Figure 1e and f).

Expression of smooth muscle actin and calponin In sclerotic fibroadenomas, the expression of smooth muscle actin and calponin was very low or undetectable; on the contrary, cellular fibroadenomas showed focal (six cases) (23\%) or diffuse (20 cases) $(77 \%)$ expression of at least one of the two markers. Moreover, smooth muscle differentiation significantly correlated with ER- $\beta$ expression (Figure 3) and the double immunostaining confirmed the coexpression of nuclear ER- $\beta$ and cytoplasmic smooth muscle actin in the same stromal cell (Figure 4a). In benign (21/30) phyllodes tumors, smooth muscle differentiation matched the nuclear expression of ER- $\beta$, being prevalent in cases expressing high levels of the receptor (Figures 3 and 4b). Smooth muscle differentiation was observed in all borderline phyllodes tumors and in three out of four cases of malignant phyllodes tumors with high ER- $\beta$ level (Figures 3 and 4c). The metastasis of one of these cases showed diffuse expression of both smooth muscle differentiation markers and ER- $\beta$ (Figures 3 and $4 d$ ).

\section{ER- $\beta$ expression and patient age}

The correlation between percentage of ER- $\beta$ expression in fibroadenomas and phyllodes tumors and the age of patients is shown in Figure 5. In 

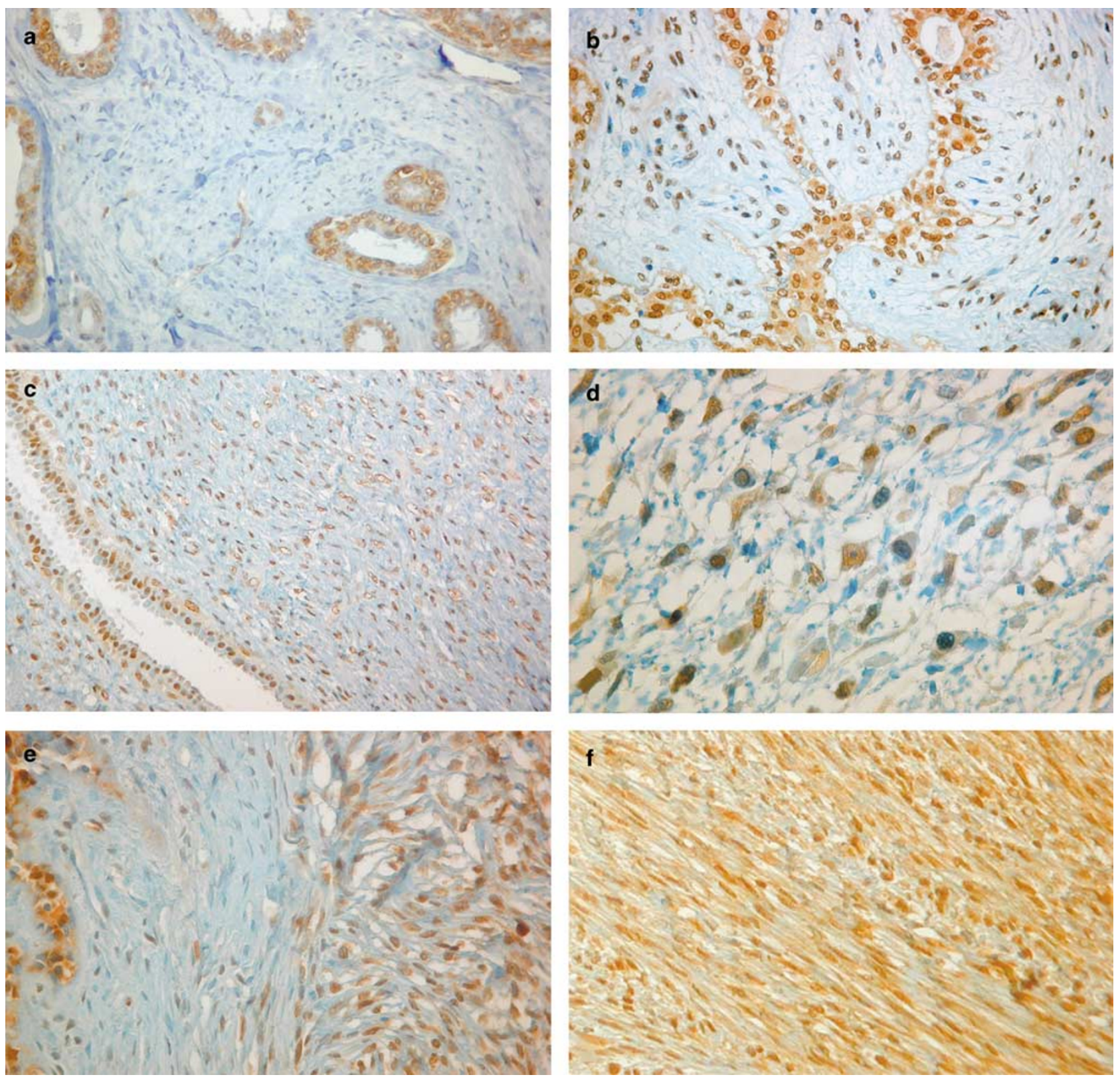

Figure 1 ER- $\beta$ immunostaining in stromal cells. (a) Sclerotic fibroadenoma; intense nuclear staining is shown only by epithelial, myoepithelial and endothelial cells. (b) Cellular fibroadenoma, (c) benign phyllodes tumor, (d) borderline phyllodes tumor, (e) primary malignant phyllodes tumor and (f) its metastasis: in all these lesions, the stromal cells show positive nuclei.

fibroadenomas, the percentage of ER- $\beta$ expression was inversely correlated with the age of patients. In fact, the mean age of patients with cellular fibroadenomas with high or moderate levels of ER- $\beta$ expression was significantly lower (mean: 33.6 years, range: 16-46) than that of patients with sclerotic fibroadenomas (mean: 47.6 years, range: 40-67), or that of patients with cellular fibroadenomas expressing low level of ER- $\beta$ (mean: 50.5 years, range 49-57). In contrast, in benign phyllodes tumors, the high level of ER- $\beta$ expression correlated with an older age. All patients with malignant phyllodes tumor were in their sixth decade of life.

\section{ER- $\beta$ and ER- $\alpha$ mRNA analysis}

To confirm the specificity of the immunohistochemical results, we also demonstrated ER- $\beta$ gene expression by means of RT-PCR of mRNA extracted from microdissected and not microdissected stroma of fibroadenomas and phyllodes tumors. As shown in Figure 6, only the case of nonmicrodissected fibroadenomas expressed ER- $\alpha$ mRNA (lane 2), as a consequence of the presence of glandular epithelial cells, as confirmed by immunohistochemistry. Microdissected stromal compartment of the other cases did not show any evidence of ER- $\alpha$ mRNA. 


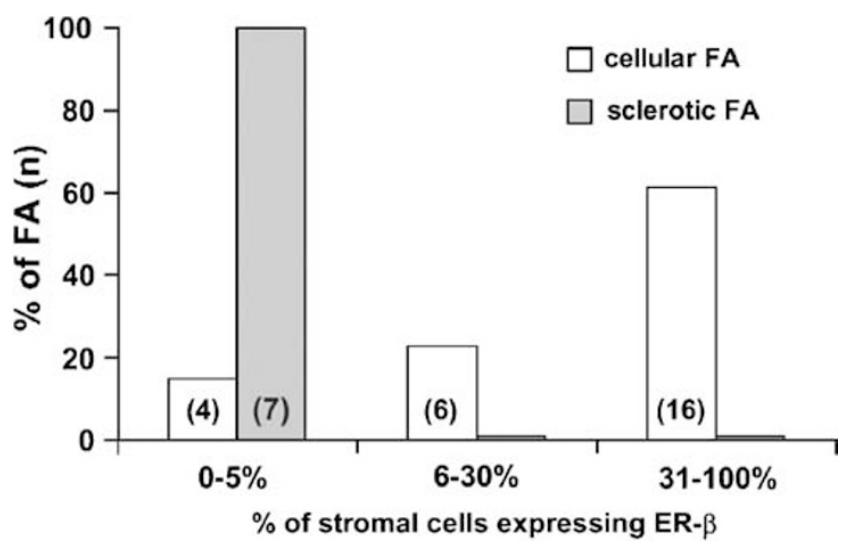

Figure 2 Relationship between stromal cellularity (empty bars)/ sclerosis (solid bars) and stromal expression of ER- $\beta$ in fibroadenomas. $\chi^{2}$ test: significant difference in low $(0-5 \%)$ vs moderate $(6-30 \%)(P=0.04)$ ER- $\beta$ expression in sclerotic fibroadenomas and low $(0-5 \%)$ vs high $(31-100 \%)(P=0.001)$ in cellular fibroadenomas.

Conversely, ER- $\beta 1$ (wild type) mRNA was detected in fibroadenomas (lanes 2, 3 and 4) and malignant primary and metastatic phyllodes tumors (lanes 5 and 6). The ER- $\beta 2,3,4$ and 5 variants were not detected in any of the specimens examined.

\section{Discussion}

In the present study, we demonstrate that ER- $\beta$ is expressed by stromal cells of fibroadenomas and phyllodes tumors both at the protein and the mRNA level, and that such expression is related to smooth muscle differentiation of stromal cells and to the age of patients.

The stroma of the adult human and rodent mammary glands expresses ER- $\beta$, but not ER$\alpha .^{11,15,16}$ The results of the present study confirm the absence of ER- $\alpha$ expression in stromal cells of fibroadenomas and phyllodes tumors and demonstrate the expression of the wild-type ER- $\beta$, but not of the other ER- $\beta$ variants.

The role of ER- $\beta$ in the mammary gland epithelium has been widely studied, but, to our knowledge, no function for ER- $\beta$ in stroma has been reported. Our results suggest that, in addition to a well established antiproliferative effect on epithelial cells, ${ }^{17}$ the expression of ER- $\beta$ in the breast is probably related to a prodifferentiative function on stromal cells. In fact, we here demonstrate that in fibroadenomas and phyllodes tumors, ER- $\beta$ expression goes in parallel with a smooth muscle differentiated phenotype of stromal cells, these cells being positive for ER- $\beta$, smooth muscle actin and/ or calponin by double immunostaining. ER- $\beta$ expression by mature smooth muscle cells of vessels ${ }^{18}$ and uterus ${ }^{13,19}$ may be crucial in the physiological response to ER-mediated transcriptional activity; our results suggest that ER- $\beta$ may also act on the
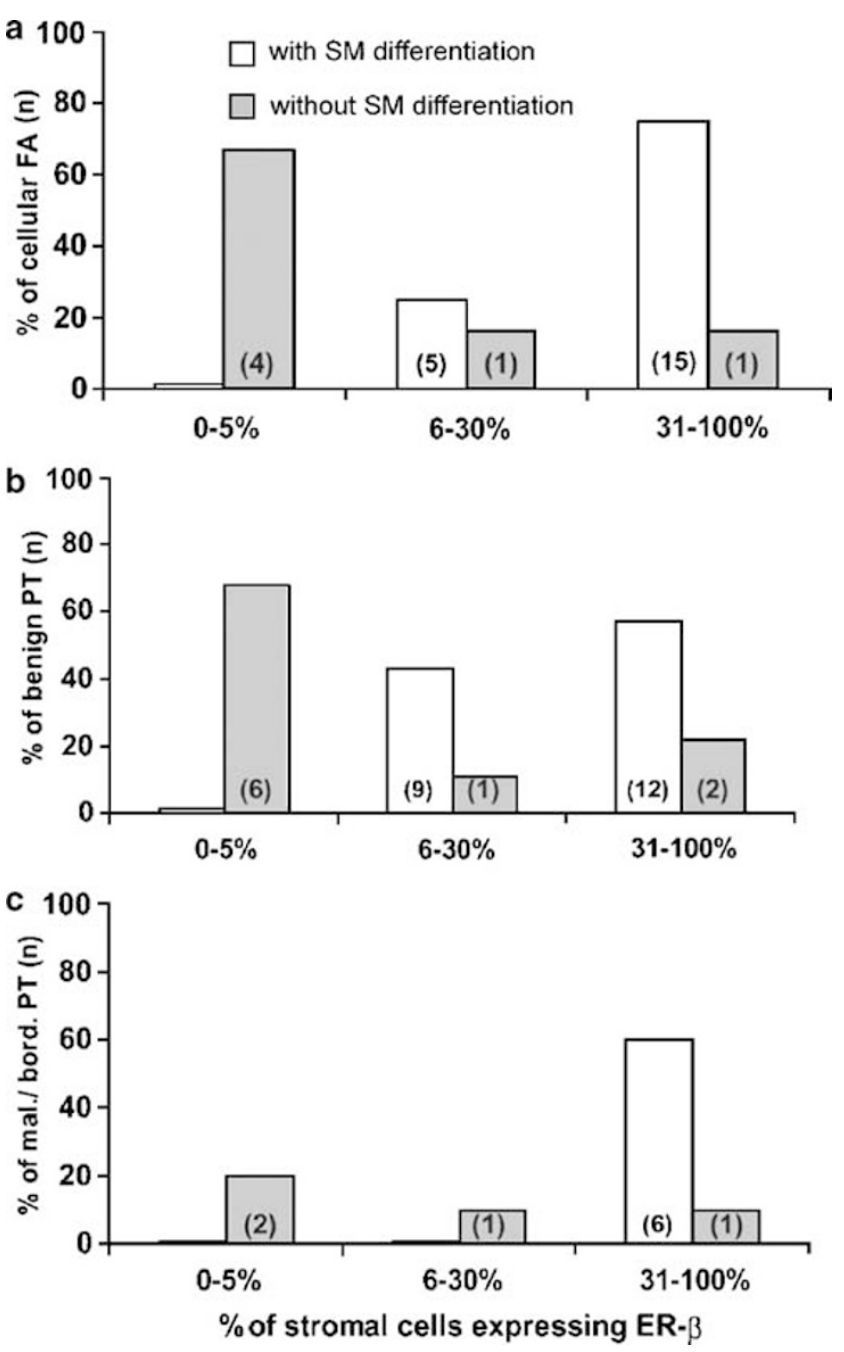

Figure 3 Relationship between smooth muscle differentiation and ER- $\beta$ expression in cellular fibroadenomas (a), benign phyllodes tumors (b) borderline and malignant phyllodes tumors (c). $\chi^{2}$ test: significant difference in low $(0-5 \%)$ vs moderate (6$30 \%)(P=0.005)$ ER- $\beta$ expression in non-smooth muscle-differentiated lesions and in low $(0-5 \%)$ vs high $(31-100 \%)(P=0.001)$ ER- $\beta$ expression in smooth muscle-differentiated lesions.

differentiation process of fibroblasts towards a myofibroblastic phenotype. Previous works have shown the expression of smooth muscle actin by stromal cells of fibroepithelial lesions of the breast and a myofibroblastic phenotype of stromal cells of fibroadenomas and phyllodes tumors ${ }^{20,21}$ has been confirmed by immunohistochemistry and electron microscopy. ${ }^{22,23}$ In addition, similarly to our results, in the uterus ER- $\beta$ is detectable exclusively in myofibroblastic differentiated decidual cells of the stroma expressing desmin and actin. ${ }^{19,24}$ Moreover, the possible hormone responsiveness of ER- $\beta$-positive stromal cells is indirectly confirmed by clinical studies showing that an increased risk of fibroadenoma is associated with estrogen replacement therapy in postmenopausal women. ${ }^{25}$ In the present study, the activation of a hormonal mechanism 

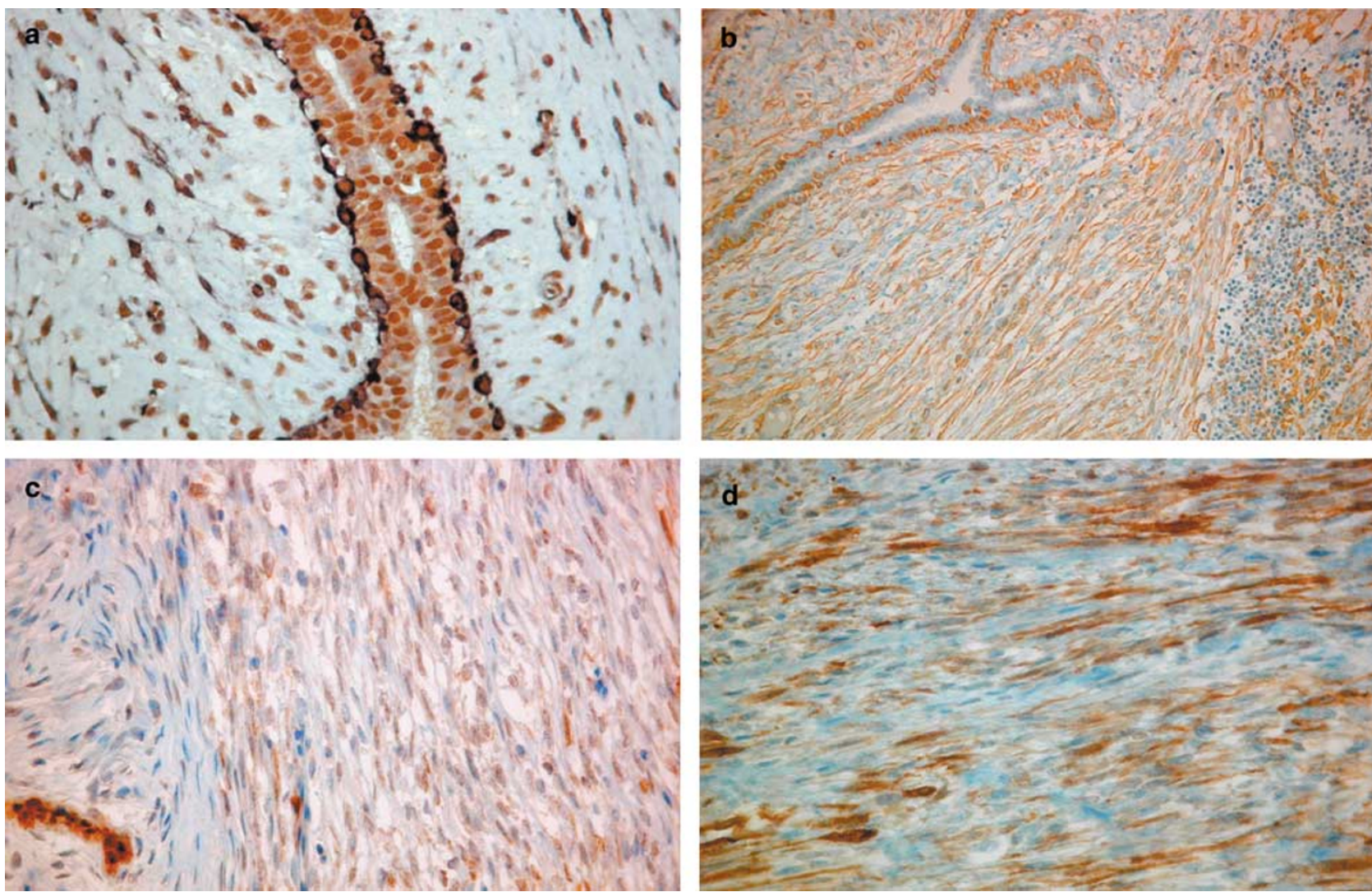

Figure 4 Smooth muscle differentiation of stromal cells. (a) Double immunostaining of a cellular fibroadenoma; ER- $\beta$ (brown nuclei) and smooth muscle actin (black cytoplasm) are coexpressed by stromal cells. (b) Benign phyllodes tumor; smooth muscle actin immunostaining. (c) Primary malignant phyllodes tumor and (d) its metastasis; calponin immunostaining.
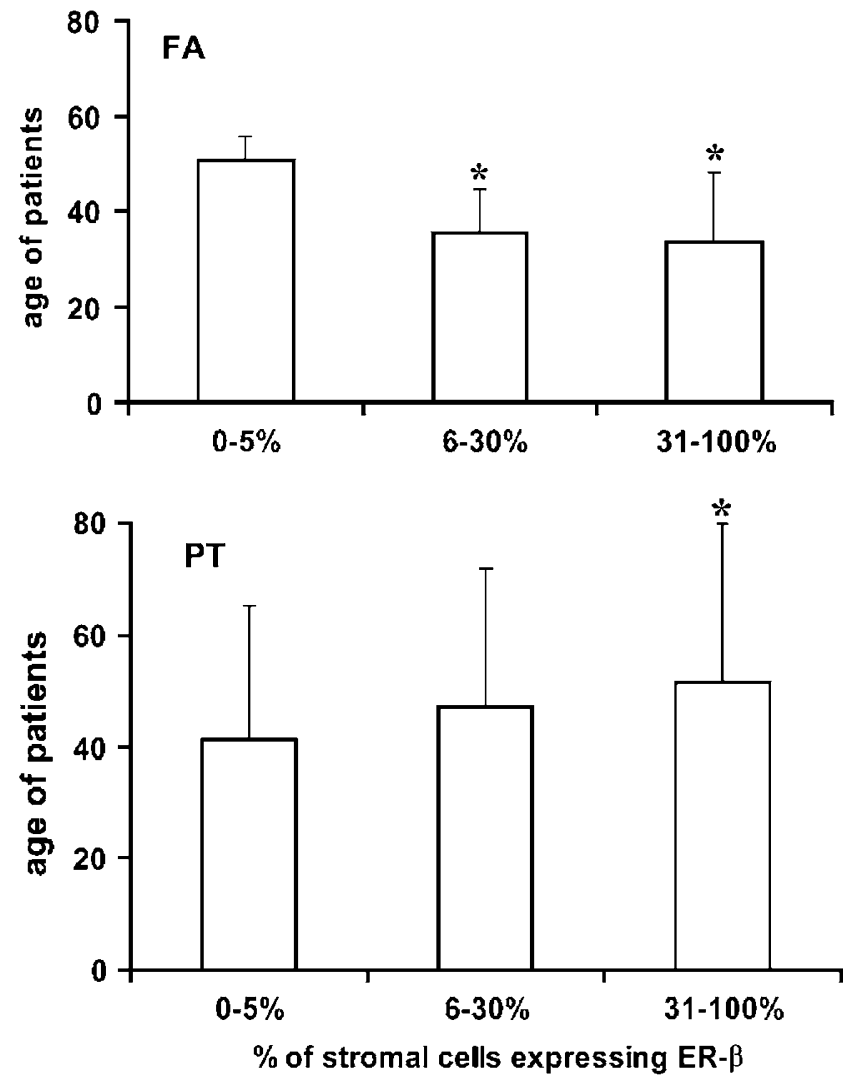

mediated by ER- $\beta$ may be suggested, since the expression of ER- $\beta$ is particularly high in cases of cellular fibroadenomas of young patients, in contrast to sclerotic fibroadenomas of elderly. However, the level of proliferative activity tested by Ki67 (data not shown) is very low in both type of fibroadenomas. Thus, the increase in size of fibroadenomas in young age and their progressive sclerotic involution is more probably an effect mediated by ER- $\beta$ on myofibroblastic differentiation and on the extracellular matrix remodelling. It is known that ER- $\beta$ is involved in elastin and collagen homeostasis either through transcriptional effects on their genes or through regulation of some of the proteases that are involved in the degradation of these proteins. ${ }^{18,26}$ There is evidence from a variety of tissues that both male and female sex steroids regulate the extracellular matrix at different levels: specifically, $17-\beta$ estradiol is known to reduce collagen biosynthesis. ${ }^{18,27}$ In fact, estrogens protect against progression of glomerulosclerosis ${ }^{27}$ and in menopause low

Figure 5 Relationship between age and ER- $\beta$ expression in fibroadenomas and phyllodes tumors. Independent samples $t$ test: in fibroadenomas, ER- $\beta$ expression inversely correlates with patients age $\left({ }^{*} P<0.04\right.$, low expression vs intermediate and high expression). In phyllodes tumor, ER- $\beta$ expression directly correlates with patient age $\left({ }^{*} P<0.001\right.$, high vs low and moderate ER- $\beta$ expression). 


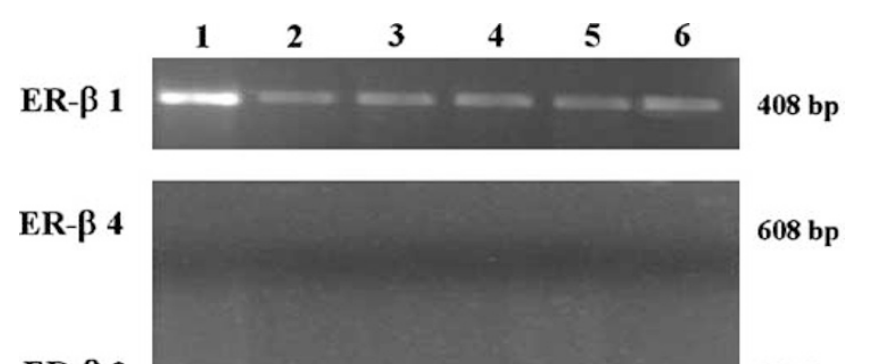

ER- $\beta 2$

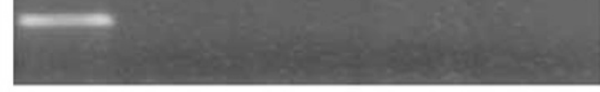

ER- $\beta 3$

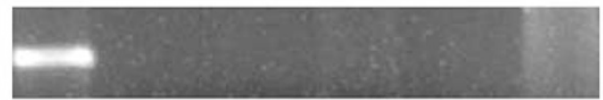

$400 \mathrm{bp}$

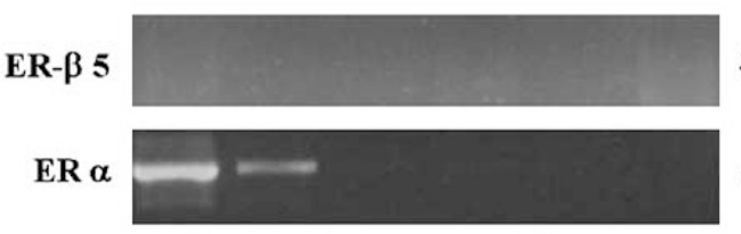

372 bp

$\beta-\mathbf{A C T}$

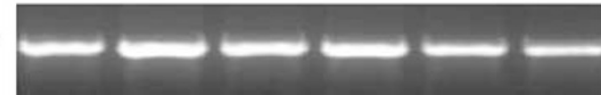

885 bp

Figure 6 RT-PCR for ER- $\beta$ isoforms and ER- $\alpha$. Lane 1: positive controls (MDA-MB231 cells for ER- $\beta$ isoforms and MCF-7 cells for ER- $\alpha$ ). Lane 2: non-microdissected fibroadenomas expressed ER$\beta 1$ and ER- $\alpha$ mRNA. Lanes 3 and 4 , microdissected stroma of cellular fibroadenomas and lanes 5 and 6 , primary and metastatic phyllodes tumors express only ER- $\beta 1$; all the other ER- $\beta$ isoforms and ER- $\alpha$ are not detectable.

levels of estrogens increase the arterial stiffness. ${ }^{18}$ Possibly, a similar mechanism may occur in fibroadenomas of elderly patients, where the low level of estrogen may increase collagen deposition and sclerosis process, inhibiting the matrix turnover mediated by stromal cells through ER- $\beta$ activation.

In contrast to these data, ER- $\beta$ expression was directly correlated to the age of patients in phyllodes tumors, suggesting an estrogen-independent tumor growth, possibly mediated by cytokines. It has been reported that ER- $\beta$ controls platelet-derived growth factor (PDGF), ${ }^{28}$ a cytokine regulating the growth and the differentiation of fibroblasts into myofibroblasts. ${ }^{29}$ Interestingly, PDGF is commonly expressed together with its receptors in the stroma of phyllodes tumor and rarely in fibroadenoma. ${ }^{30}$ An ER- $\beta$ PDGF pathway could therefore be involved in the smooth muscle differentiation in these lesions. Alternatively, recent findings indicate that cytosolic ER may modulate the activity of other transcriptional factors and in particular AP-1. ${ }^{31}$ This complex is known to regulate fibroblast activation and proliferation $^{32}$ and myofibroblastic differentiation. ${ }^{33}$

In conclusion, the present work suggests that a heterogeneous fibroblast population with different lifespan is activated and recruited through ER- $\beta$ in the stroma of fibroadenomas and phyllodes tumors. In fibroadenomas, ER- $\beta$-related myofibroblastic differentiation of fibroblasts may act on remodelling of the matrix and inhibition of the sclerotic involution. On the other hand, the expression of ER- $\beta$ observed in phyllodes tumors leads to the assumption that in some cases the clonal proliferation of stromal cells described in these tumors ${ }^{1}$ may be modulated through ER- $\beta$ activation, suggesting, thus, the potential use of ER- $\beta$-selective agonists ${ }^{34}$ as a new therapeutic option in malignant phyllodes tumors.

\section{Acknowledgements}

This work was supported by grants from the Ministry for Universities, Instruction and Research (MIUR), Rome, Italy; MURST (ex 60\%), Rome, Italy; the Compagnia di San Paolo/FIRMS, Torino, Italy. Gábor Cserni was supported by a János Bolyai Research Fellowship from the Hungarian Academy of Sciences.

\section{References}

1 Kuijper A, Buerger H, Simon R, et al. Analysis of the progression of fibroepithelial tumours of the breast by PCR-based clonality assay. J Pathol 2002;197:575-581.

2 Haaghensen CD. Adenofibroma. In: W.B. Saunders Company (eds). Disease of the Breast. W.B. Saunders Company: Philadelphia, London, Toronto, Mexico City, Rio de Janeiro, Sydney, Tokyo, Honk Kong, 1986, pp 267-283.

3 Dixon JM. Cystic disease and fibroadenoma of the breast: natural history and relation to breast cancer risk. Br Med Bull 1991;47:258-271.

4 Martin PM, Kuttenn F, Serment H, et al. Studies on clinical, hormonal and pathological correlations in breast fibroadenomas. J Steroid Biochem 1978;9: 1251-1255.

5 Hefler LA, Tempfer CB, Grimm C, et al. Estrogenmetabolizing gene polymorphisms in the assessment of breast carcinoma risk and fibroadenoma risk in Caucasian women. Cancer 2004;101:264-269.

6 Bernardes Jr JR, Seixas MT, Lima GR, et al. The effect of tamoxifen on PCNA expression in fibroadenomas. Breast J 2003;9:302-306.

7 Mechtersheimer G, Kruger KH, Born IA, et al. Antigenic profile of mammary fibroadeonoma and cystosarcoma phyllodes. Pathol Res Pract 1990;186:427-438.

8 Umekita Y, Yoshida H. Immunohistochemical study of hormone receptor and hormone regulated protein expression in phyllodes tumors: comparison with fibroadenoma. Virchows Arch 1998;433:311-314.

9 Shoker BS, Jarvis C, Clarke RB, et al. Abnormal regulation of the oestrogen receptor in benign breast lesions. J Clin Pathol 2000;53:778-783.

10 Tse GM, Lee CS, Kung FY, et al. Hormonal receptors expression in epithelial cells of mammary phyllodes tumor correlates with pathologic grade of the tumor: a multicenter study of 143 cases. Am J Clin Pathol 2002; 118:522-526.

11 Palmieri C, Saji S, Sakaguchi H, et al. The expression of oestrogen receptor (ER)-beta and its variants, but not ERalpha, in adult human mammary fibroblasts. J Mol Endocrinol 2004;33:35-50. 
12 Di Tommaso L, Pasquinelli G, Damiani S. Smooth muscle cell differentiation in mammary stromo-epithelial lesions with evidence of a dual origin: stromal myofibroblasts and myoepithelial cells. Histopathology 2003;42:448-456.

13 Gargett CE, Bucak K, Zaitseva M, et al. Estrogen receptor-alpha and -beta expression in microvascular endothelial cells and smooth muscle cells of myometrium and leiomyoma. Mol Hum Reprod 2002;8: 770-775.

14 Skliris GP, Parkes AT, Limer JL, et al. Evaluation of seven oestrogen receptor beta antibodies for immunohistochemistry, Western blotting, and flow cytometry in human breast tissue. J Pathol 2002;197:155-162.

15 Saji S, Jensen EV, Nilsson S, et al. Estrogen receptors $\alpha$ and $\beta$ in the rodent mammary gland. Proc Natl Acad Sci USA 2000;97:337-342.

16 Shyamala G, Singh RK, Ruh MF, et al. Relationships between mammary estrogen receptor and estrogenic sensitivity. II. Binding of cytoplasmic receptor to chromatin. Endocrinology 1986;119:819-826.

17 Strom A, Hartman J, Foster JS, et al. Estrogen receptor $\beta$ inhibits 17- $\beta$-estradiol-stimulated proliferation of the breast cancer cell line T47D. Proc Natl Acad Sci USA 2004;101:1566-1571.

18 Natoli AK, Medley TL, Ahimastos AA, et al. Sex steroids modulate human aortic smooth muscle cell matrix protein deposition and matrix metalloproteinase expression. Hypertension 2005;46:1129-1134.

19 Lecce G, Meduri G, Ancelin M, et al. Presence of estrogen receptor beta in the human endometrium through the cycle: expression in glandular, stromal, and vascular cells. J Clin Endocrinol Metab 2001;86: 1379-1386.

20 Chen CM, Chen CJ, Chan CL, et al. CD34, CD117 and actin expression in phyllodes tumor of the breast. J Surg Res 2000;94:84-91.

21 Burga AM, Tavassoli FA. Periductal stromal tumor: a rare lesion with low-grade sarcomatous behavior. Am J Surg Pathol 2003;27:343-348.

22 Auger M, Hanna W, Kahn HJ. Cystosarcoma phylloides of the breast and its mimics. An immunohistochemical and ultrastructural study. Arch Pathol Lab Med 1989;113:1231-1235.
23 Shimizu T, Ebihara Y, Serizawa H, et al. Histopathological study of stromal smooth muscle cells in fibroadenoma of the breast. Pathol Int 1996;46: 442-449.

24 Oliver C, Montes MJ, Galindo JA, et al. Human decidual stromal cells express alpha-smooth muscle actin and show ultrastructural similarities with myofibroblasts. Hum Reprod 1999;14:1599-1605.

25 Trapido EJ, Brinton LA, Schairer C, et al. Estrogen replacement therapy and benign breast disease. J Natl Cancer Inst 1984;73:1101-1105.

26 Pilka R, Norata GD, Domanski H, et al. Matrix metalloproteinase-26 (matrilysin-2) expression is high in endometrial hyperplasia and decreases with loss of histological differentiation in endometrial cancer. Gynecol Oncol 2004;94:661-670.

27 Potier M, Elliot SJ, Tack I, et al. Expression and regulation of estrogen receptors in mesangial cells: influence on matrix metalloproteinase-9. J Am Soc Nephrol 2001;12:241-251.

28 Patrone C, Cassel TN, Pettersson K, et al. Regulation of postnatal lung development and homeostasis by estrogen receptor beta. Mol Cell Biol 2003;23: 8542-8552.

29 Kilarski WW, Jura N, Gerwins P. An ex vivo model for functional studies of myofibroblasts. Lab Invest 2005; 85:643-654.

30 Feakins RM, Wells CA, Young KA, et al. Plateletderived growth factor expression in phyllodes tumors and fibroadenomas of the breast. Hum Pathol 2000; 31:1214-1222.

31 Bjornstrom L, Sjoberg M. Estrogen receptor-dependent activation of AP-1 via non-genomic signalling. Nucl Recept 2004;14:1-11.

32 Gagliardi M, Maynard S, Miyake T, et al. Opposing roles of C/EBPbeta and AP-1 in the control of fibroblast proliferation and growth arrest-specific gene expression. J Biol Chem 2003;278:43846-43854.

33 Fitzner B, Sparmann G, Emmrich J, et al. Involvement of AP-1 proteins in pancreatic stellate cell activation in vitro. Int J Colorectal Dis 2004;19:414-420.

34 Koehler KF, Helguero LA, Haldose'n L-A, et al. Reflections on the discovery and significance of estrogen receptor $\beta$. Endocrine Rev 2005;26:465-478. 